\title{
James Cone and the Crisis of American Theology
}

\section{Celucien Joseph ${ }^{1}$}

\section{Abstract}

The objective of this essay is to investigate the public function of Christian theology in the (politico-theological writings and hermeneutics of James $\mathrm{H}$. Cone. It is also to articulate a critique of white American theology. In Cone's work, Christian theology is expressed as a public discourse and testimony of God's continuing emancipative movements and empowering presence in society with the goal (1) to set the oppressed and the vulnerable free, (2) to readjust the things of the world toward divine justice and peace, and (3) to bring healing and restoration to the places in which volitional (human) agents have inflicted pain, suffering, oppression, and all forms of evil. This essay is an attempt to imagine creatively with new hermeneutical lenses and approaches-anti-imperial, liberative, and postcolonial-the task of Christian theology as public witness to carry out the emancipative agenda and reconciling mission (salvation, healing, hospitality, wholeness, reconciliation, and peace) of God in contemporary societies and in our postcolonial moments. The basic argument of this essay is twofold. First, it contends for the essential role of liberation theology as a public witness in redefining Christian theology in general. Rather than being a "special interest" or merely political theme in theology, it suggests that black liberation theology has a special role to play in "freeing" Christian theology from racism, oppression, and imperialism. Second, by promoting some new understanding of Cone's work and applying it in some new context, this article is deploying Cone's public theology to critique or awaken dominant white theology to a new way of thinking about the whole field of theology in the 21 st century.

Keywords: James H. Cone, Black Liberation Theology, Anti-Black Racism, White American Theology, White American Church

\section{Introduction}

James H. Cone articulates a Black theology of liberation in the context of the history of black suffering and white domination in the U.S. and frames it as a corrective response to American (white) theology that is silent on black pain and suffering and the alienation of Black people from white theological account about God's involvement in human history. Cone (2004:9) defines Black Theology as a "radical response from the underside of American religious history to the mainstream of white Christianity." In his second and seminal work, A Black Theology of Libera-

1 Associate Professor of English, Department of English, Communication, and Modern Languages, Indian River State College 
tion, Cone (2010:9) argues that Christian "theology cannot be separated from the community it represents. It assumes that truth has been given to the community at the moment of its birth. Its task is to analyze the implications of that truth, in order to make sure that the community remains committed to that which defines its existence." The relationship between theology and ecclesiology is intertwined in Cone's theological language and reasoning. The concerns and experiences of the people of God in the church are the raw material for theological hermeneutics and the reading of God's liberating actions among his people.

While Cone prioritizes God's revelation as the beginning point of theological inquiry, correspondingly, he contends that the culture of a people is another fundamentally adequate source to think theologically about the redemptive movement of God in the world. Consequently, Cone establishes that theology has both a communal function and public vocation in relation to the needs of the Christian community and the needs of the people in society that contextualize and inform theological imagination and hermeneutics. As there are complexities of human relations in society, if Christian theology is going to be a faithful witness to God's active involvement in human affairs, it must contribute to the wholistic transformation of the human condition in society and the reconciliation of all things through Christ the Liberator. Christian theology as an academic discipline must not remain unresponsive to the plot of the oppressed and the vulnerable in society.

The objective of this essay is to investigate the public function of Christian theology in the politico-theological writings and hermeneutics of James H. Cone. It is also to articulate a critique of white American theology. In Cone's work, Christian theology is expressed as a public discourse and testimony of God's continuing emancipative movements and empowering presence in society with three goals, namely; (1) to set the oppressed and the vulnerable free, (2) to readjust the things of the world toward divine justice and peace, and (3) to bring healing and restoration to the places in which volitional (human) agents have inflicted pain, suffering, oppression, and all forms of evil. This essay is an attempt to imagine creatively with new hermeneutical lenses and approaches-anti-imperial, liberative, and postcolonial-the task of Christian theology as public witness to carry out the emancipative agenda and reconciling mission (salvation, healing, hospitality, wholeness, reconciliation, and peace) of God in contemporary societies and in our postcolonial moments.

The basic argument of this essay is twofold. First, it contends for the essential role of liberation theology as a public witness in redefining Christian theology in general. Rather than being a "special interest" or merely political theme in theology, it suggests that black liberation theology has a special role to play in "freeing" Christian theology from racism, oppression, and imperialism. Second, by promoting some new under- 
standing of Cone's work and applying it in some new context, this article is deploying Cone's public theology to critique or awaken dominant white theology to a new way of thinking about the whole field of theology in the 21st century.

Broadly, the essay is divided into three parts. Briefly, the first part discusses the complexity of race in the history of American Christianity; particularly, it provides some historical examples of how white supremacy completely distorts theology and race relations in America. By providing three main examples, the second part of the essay demonstrates the bankruptcy of white American theology and Cone's constructive criticisms to white theological discourse. Particularly, it showcases how an "other worldly" Christianity consistently dehumanizes the black other, but also mangles Christian theology itself into a mere cover for human oppression. Finally, the third part discusses the task of Christian theology in the quest for human flourishing. It demonstrates how Cone's project of black liberation affirms the humanity and agency of the oppressed and has the potential to redefine Christianity for all people as this-worldly, engaged, situated, and attuned to the healing of suffering in the present, rather than Christianity as other worldly ideology covering racism, oppression, and imperialism.

\section{Theology and Race in "Christian America"}

The introductory article of The Universal Declaration of Human Rights (1948) that bears considerable political ideologies and linguistic parallels with The Constitution of the U.S. and The Bill of Rights (1791) and France's Declaration of the Rights of the Man and of the Citizen (1789) begins with the following declaration: "Whereas recognition of the inherent dignity and of the equal and inalienable rights of all members of the human family is the foundation of freedom." Both historical documents were written in the blossoming era of the transatlantic slave trade and the flourishing of the institution of slavery in the slaveholding North America and French Caribbean colonies. The practice of racial slavery in the newly-independent and republic of the U.S. violated the very inalienable rights of the enslaved African population the U.S. Constitution and its Bill of Rights promised to all people.

Not only the systemic oppression of blacks through the institution of slavery robbed the enslaved of their honor and humanity, anti-black racism equally demoralized and culturally alienated them in the American society. Unquestionably, racism is a question of human respect and honor. Ghanaian-born philosopher Kwame Anthony Appiah (2011:104) interprets the American racial slavery as "the subordination of one race by another and it entailed the systematic subjection of black people to dishonor." Unfortunately, the history of racism as America's great moral failure and the dishonor of black lives is linked to America's theological conviction and religious habitus. 
The American experience is captured within five central "American ideologies" that tell a distinctive story of American Christian expression, the country's theological development, and the interplay between Americans' attitude toward race and the triumph of American freedom and unfreedom. These ideologies also explain the history of internal wars, oppression, violence, and dehumanization that have marked the life of America's people of colour and the disfranchised poor. The complex relations between black and white Americans, and the people of European descent and those of non-European ancestry living in America correspondingly provide an important window to make sense of the triumph of white supremacy, racial segregation in American churches and society, and the economic injustice toward the poor and the mistreatment of racialized Americans. Below, I highlight the five cardinal American ideals and beliefs already signaled above:

1. Election of God: The idea that America is a Christian nation distinctively chosen and called by God to protect and bring American freedom to the developing nations, and to bear witness of God's blessings in America to the world.

2. Racial Purity: The concept that America is a white nation, and for many white Americans, it entails the natural separation of the two major races, the black and white races, and the maintenance of the supremacy of the white race in all human affairs and transactions.

3. Slavery: For many white Christian Americans and non-Christian white racists, the enslavement of Africans in the country of America was a divine sanction and the institution of slavery should be construed as God's predestining choice of the Africans to be brought to America, so they could be exposed to the light of the Gospel and receive the grace of Christ's forgiveness and salvation.

4. White Christianity and White Theology: The belief in the white version of Christianity and white articulation of Christian theology is prominent among both white American Christians and white American theologians; it is connected to the ideology of the divine election of America as a white and Christian nation, and that the "white church" and the theological reflections done by white religious thinkers are the best models to imitate and to think theologically and Christianly.

5. Jim Crow segregation (the 1896 Supreme Court doctrine of "separate but equal"): The American legal system of racial segregation, similar to the South African apartheid, was a means to purify the white race and control the black race, and to keep each race in its God-ordaining roles and functions in public spaces; racial segregation flourished through various invented systems and institutions including; (1) the legal prohibition of interracial relationships and marriage between white and black Americans, (2) the lynching era (18891940) in which black bodies were publicly and unashamedly displayed in 
Southern trees, and (3) the separation of black and white Christian churches in worship and other religious activity, and the defense of this religious attitude through the reproduction and dissemination of an idiosyncratically-American white theology framed by the race question, and the disfranchisement of America's black population.

As a result, historically, white supremacy in the American life has manifested itself in three broad traumatic events: the harshness of slavery, Jim Crow segregation, and the public lynching of black people. The five underlying factors outlined above would lead to a web of complex relations: the emergence of various protest and cultural-political movements throughout American history, from the eighteenth to the first-half of the 20th century, the creation of African American Christianity ("The Black Church"), what we may call "Black religious tradition," as a counterreligious movement to White Christian hegemony during the time of slavery; subsequently, the development of the Civil Rights Movement, the social-political and moral activism of Martin Luther King, Jr., the emergence of Black Power Movement, and the birth of Black Theology could be traced historically to the 1960s-an era in which Blacks proclaimed their humanity in the midst of cultural despair, white terror, and existential alienation.

These major events and ideologies are watershed moments in Black theology and American history. They represent very specific historical contexts to understand the politico-theology and intellectual ideas of James $\mathrm{H}$. Cone, and the fortification of American Christianity and White American theology. Based on our limitation in this essay, we will not develop these five topics, but will concentrate on Cone's interaction with American theology and the American church in these fragile moments. Yet, Black religious tradition, and Black liberation theology would modify the content and contours of American religious thought and social history.

\section{Blackness as Alienation and Social Death in the American Society}

People who live in the U.S. and who do not share a European lineage, have also immensely experienced the oppression and evil of the American empire, which historically changed their relationships with the American state. For example, the Native American people were tragically tortured and dehumanized in the era of the Trails of Tears (1831-1850); those from China bravely endured The Chinese Exclusion Act (1882); the Japanese were brutalized and tortured in the Japanese internment camps $(1942$ - 1945). The American empire is an empire of death and human annihilation. According to the South African Liberation Theologian, Vuyani Vellem (2015:1-2); not only "Empire is life denying," for the victims of the American and European empires, "living against the logic of Empire is rebellion against the life killing order of Empire." 
The validity and worth of black life in America have always been a matter of cultural curiosity, contestation, and intellectual uncertainty. The racial structure of the nation and the anti-black narrative inherent in the American psyche make black identity a curse and a symbolic void. Working within the rhetoric of existential philosophy (i.e. Sartre, Camus, and Fanon), James Cone describes the dialectics of blackness and whiteness in this powerful language:

The structure of white society attempts to make "black being" into "nonbeing" or "nothingness." In existential philosophy, nonbeing is usually identified as that which threatens being; it is that ever-present possibility of the inability to affirm one's existence. The courage to be, then, is the courage to affirm one's being by striking out at the dehumanizing forces which threaten being." (2008:7)

The fundamental binary opposition between black and white can be traced to the history of the Early Republic. In 1706, the influential New England Puritan Minister Cotton Mather published an ambivalent pro-slavery pamphlet entitled The Negro Christianized, a Christian pedagogy on the spiritualization of American racial slavery. Although he published the religious essay anonymously, it was well known among the people in the colony that Mather has authored the work; Mather and many Christians in his New England congregation were slave merchants and slave owners. One of the central propositions he makes in this evangelistic work was for Christian masters to educate their slaves in the Christian religion and to treat them kindly as their spiritual brethren (1706:2). Nonetheless, Mather's central argument is that the Christian master has "a moral responsibility for the souls of those in danger, and the Christianized servant is more profitable to his master" (1706:2-3).

The puzzling issue about Mather's pro-slavery Christian ideology was his belief that it was God who had sovereignly ordained the servitude of the Africans in the newly-conquered land of the Native Americans. Second, it was also God who had appointed freely the enslaved African population, whom he termed humorously "Rational Creatures," to be the "Servants" of white (Christian) masters (1706:3). Having established a close rapport between American Christianity and American slavery, Mather instructed Christian masters in these well-crafted religious precepts:

The greatest Kindness that can be done to any Man is to make a Christian of him. Your Negroes are immediately Raised unto an astonishing Felicity, when you have Christianized them. They are become amiable spectacles, such as the Angels of God would gladly repair unto the Windows of Heaven to look upon. Tho' they remain your servants, yet they are become the Children of God. Tho' they are to enjoy no earthly goods, but the small Allowance that your Justice and Bounty shall see proper for them, yet they are become Heirs of God, and Joint-Heirs with the Lord Jesus Christ. (Mather, 1706:12) 
For Mather, to be a Christian and an owner of slaves was not a theological tension. He also reminds the Christian slave owners in the colony of their role as masters, and of the unfreedom and constraints of their enslaved as servants.

Tho' they are your Vassals, and must with a profound subjection wait upon you, yet the Angels of God now take them under their Guardianship and vouchsafe to tend upon them. Oh! what have you done for them! Happy Masters, who are Instrumental to raise their Servants thus from the Dust and make them objects for the Nobles of Heaven to take Notice of! But it will not be long before you and they come at length to be together in the Heavenly City. (Mather, 1706:12)

Mather employs various epithets to establish a sense of connection between the masters and their slaves; the latter are called "your servants" and "your vassals," which are intended to convey a relationship of domination and subjectivity between the two entities. In the same rhetorical pattern, he uses different felicitous terms for the Christian slave masters including "happy masters," "pious masters," and "our masters." These titles aimed at conveying the dignity of the New England Christian community that was engaged actively in the selling of human (Black) flesh for profit - with the blessing of the colonial American church. He assures Christian masters that the enslaved Africans will render better service if they are indoctrinated in the Christian religion: "Be assured, Syrs; Your Servants will be the Better Servants, for being made Christian Servants" (p.12). According to Mather's judgement, the enslaved African should not be granted access to earthly advantages or privileges nor should he or she be allowed access to social mobility unless the master deems it necessary and appropriate. The welfare and happiness of the slave is determined decisively by the sovereign will of the master. While Mather proposes that the enslaved population could be denied of earthly goods, but slave masters should not withhold from them the blessings of the spiritual world.

Evidently, Mather exploited Christianity to make the slaves docile and obedient to their masters and that they could remain in their God-assigned role as slaves in colonial America. His version of Christianity did not provide any corrective and moral teachings that could radically transform the darkened soul of the Christian masters who had put their brothers and sisters in Christ in chain. The moral failure of colonial Christianity in New England lies in its inability to transform a (Christian) slaveowner to an (Christian) abolitionist. Writing from a Calvinistic-theological viewpoint, Mather (1706:11) reminded Christians that "God has brought a Servant unto thee, and said; Keep that Soul, Teach it, and Help it, that it may not be lost." Accordingly, Christian masters should never lose sight of this divine providence and kindness toward them; yet, Mather reassured them that the stupidity of the enslaved Africans was a 'discour- 
agement', and that the purpose of the individual Christian master was "to teach, as to wash" the African (pp.15-6; Kendi, 2016:47-76). Teaching and washing about the master's duty to his slave implies both the full integration of the enslaved population to the Christian faith and complete assimilation into the white-European culture and worldview-which may infer the suppression or eradication of the imported cultural values and religious practices of African slaves in the colony.

Moreover, in 1701, the colonial New England Christian merchant, politician, and judge John Staffin published A Brief and Candid Answer to a Late Printed Sheet Entitled the Selling of Joseph in response to the Boston lawyer Samuel Sewall's The Selling ofJoseph, the first anti-slavery track published in New England in 1700. Sewall's central thesis is that slavery was immoral and unlawful; it was unbiblical (for Christians) to own, buy, and sell slaves. Because of this (abolitionist) conviction, Sewall called upon the representative governing officials and authority to emancipate the enslaved population. In his counter-response, Staffin has eloquently argued that slavery as a system was "the constant practice of our own and other Christian Nations in the World," and that the institution of slavery should not be "condemned as irreligious... which is diametrically contrary to the rules and precepts which God hath given the diversity of men to observe in their respective Stations, Callings, and Conditions of Life, as hath been established" (Jehlen \& Warner, 2013:823).

Moreover, he also added, "God hath set different orders and degrees of men in the world, both in Church and Common weal" (p.823) and that it was not an "evil to bring [Africans] out of their own heathenish country" (p.823) and to convert them to the Christian religion. Like Mather, Staffin interprets the enslavement of the Africans theologically and construes this aberration as an essential facet of God's providence in human history, especially in the history of white rule and hegemony in human civilization. About the outcome of the slavery debate, historian Ibram X. Kendi (2016:68) concludes "Samuel won the battle-Adam was freed in 1703 after a long and bitter trial—but he lost the war. America did not rid itself of slavery or of black people." He also points out the bewildering correlation between white supremacy, slavery, and American Christianity, for example, in the legal system in the colonial state of Virginia.

The Virginia legislature also denied Blacks the ability to hold office. Evoking reportedly the term "Christian white servant" and defining their rights, Virginia lawmakers fully married Whiteness and Christianity, uniting rich White enslavers and the non-slaveholding White poor (Kendi, 2016:68).

Hence, the godliest and gracious duty Christian masters could render to their slaves is not emancipation from the bondage of slavery, but spiritual emancipation from the 
bondage of sin through dispensing effective religious instruction to their slaves. For Staffin and pro-slavery Christian theologians and (Puritan) ministers, slavery "was a positive good, for it enabled Africans to accept Christian truth" (Kendi, 2016:.68). Historian Sydney Ahlstrom's observation is quite insightful about this great American paradox, the dialectic of American slavery and American Christianity:

That the United States- the first new nation, the elect nation, the nation with the soul of a church, the great model of modern democracy - moved into the 19th century with one of the largest and cruelest of slave systems in its midst with full constitutional protection is surely one of the world's greatest ironies. (2004:495).

It is in the same historical perspective that the editors of Religion and the Antebellum Debate Over Slavery could come to a similar conclusion:

The reformist impulse inherent in evangelical religion did not lead inexorably to an opposition of slavery. Rather, the tenets of evangelicalism, in a different social and cultural context, could be channeled into a slaveholding ethic for maters... In denominations in which evangelicalism's impact was weak, there was usually a conservative element that declared slavery a secular matter toward which religious bodies should remain neutral... Both popular revivalists and local ministers complained that preaching against slavery would interfere with their missionary and other purely religious work (McKivijan \& Snay, 1998:5-9).

In short, slavery challenged black dignity and reduced the self-worth of black folk to non-being while white theologians and clergy correspondingly declared unapologetically and theologically the equal self-worth of every person, or as they say it in Haitian Creole "tout moun se moun" ("Every Person is a Person"). The idea that "every person has the same worth as every other is a revolutionary principle" in both (James Cone's) Black liberation theology and Third World Liberation theologies (Bigo, 1977:5). African American ethicist Peter J. Paris asserts that white American Christianity experienced no conflict between its theological thought, white Christian action, and the mistreatment of black people in America-including black Christians who share with them a common spiritual heritage; certainly, white American Christianity is less concerned about the practice of true biblical ethics or the biblical notion of justice for the advancement of the black population in society. Paris (1985:76) explains further; "Rather, in that respect, the white churches actually experienced no alienation between their thought and practice. This is evidence by the fact that any attempt to preach racial equality in the pulpits of white churches has always been viewed as an act of hostility against their prevailing ethics." The great divide between theology and ethics, thought and action, is a serious delinquent in contemporary American Evangelicalism. 


\section{The Bankruptcy of American White Theology}

For Cone, the pivotal question concerning the relationship between American white theology and black oppression in the American society is this: "how to reconcile the gospel message of liberation with the reality of black oppression" (2011, pp.: xiv-xvi). In the American experience, it is unfortunate that "the public meaning of Christianity was [is] white" (pp. xvii). American white theology is bankrupt in many ways as it maintains its silence on matters of life and death in the contemporary culture, especially life threatening-issues that confront the welfare and happiness of people of colour in the U.S. As Cone (2008:31) has remarked, "consequently there has been no sharp confrontation of the gospel with white racism."

Notably, Cone describes the bankrupt nature of American theology in this striking and powerful paragraph:

Throughout the history of this country, from the Puritans to the death-of-God theologians, the theological problems treated in white churches and theological schools are defined in such a manner that they are unrelated to the problem of being black in a white, racist society. By defining the problems of Christianity in isolation from the black condition, white theology becomes a theology of white oppressors, serving as a divine sanction from criminal acts committed against blacks. (2010:9).

Also, he establishes a pivotal rapport between God exercising his righteousness in society and vindicating the cause of the helpless against their enemies and oppressors, and the morally-wicked:

Theologians and churchmen have been of little help in this matter because much of their intellectualizing has gone into analyzing the idea of God's righteousness in a fashion far removed from the daily experiences of men. They failed to give proper emphasis to another equally, if not of more important concern, namely; the biblical idea of God's righteousness as the divine decision to vindicate the poor, the needy, and the helpless in society (Cone, 2008:43).

Besides, Cone outlines specifically seven characteristics of white theology corelating with the social fabric of America and the chronology of American history and Christianity. First, white theologians are silent about black pain and suffering, and do not confront the moral evil of anti-black racism in America. Second, white theologians seem to hold a neutral position on social, economic, and political issues concerning the oppressed and the poor; when white theologians fail to be in solidarity with those who are victimized by the dominant class, they're directly or indirectly siding with the individuals in position of power and influence in society. Third, the language of white theology does not challenge the oppressive structures of society and 
systems of power that dehumanize the poor and the vulnerable. Fourth, American white theology and American white Christianity have been overwhelmingly patriotic and in solidarity with the racist government instead of siding with the poor and God to radically transform systems of inequality and injustice to structures of equity and justice, callous hearts to sympathetic hearts.

Moreover, fifth, American white theology is unable to define human nature in the light of the Gospel for the poor and the experience of the weak in society. Rather, the human nature or human identity is defined within the structures of whiteness and white values. As Cone (2010:86) puts it, "The human person in American theology is George Washington, Thomas Jefferson, and Abraham Lincoln." Sixth, white theologians are reluctant to address or confront directly the pressing issues of this age: human poverty and greed, physical deprivation and destitution, economic dispossession and income inequality, oppression and injustice, child and sex slavery, suffering and hunger, white supremacy and racial discrimination, imperialism and capitalism (Johnson, 1986:116). Finally, American white theology has also been unsuccessful to champion better race relations, economic uplift programmes for the poor and the lower-class, to support protest activism for racial and social justice politics, and to sustain Gospel-centred peace and reconciliation conversations. As Cone thunders in this insightful and provocative paragraph:

The sin of American theology is that it has spoken without passion... When it has tried to speak for the poor, it has been so cool and calm in its analysis of human evil that it implicitly disclosed whose side it was on. Most of the time American theology has simply remained silent, ignoring the condition of the victims of this racist society. How else can we explain the theological silence during the period of white lynching of black community in this nation? How else can we explain the inability of white religionists to deal relevantly with the new phenomenon of black consciousness? And how else can we explain the problem white seminaries are having as they seek to respond to radical black demands? There is really only one answer: American theology is racist; it identifies theology as dispassionate analysis of "the tradition," unrelated to the sufferings of the oppressed. (2010:18).

Elsewhere, Cone questions the exclusive content and particularity of white theological and curriculum suggesting that white religious education is not adequate and universal for all people, contrary to the traditional belief. In so doing, seminaries in America

emphasize the need for appropriate tools in doing theology, which always means white tools, i.e., knowledge of the language and thought of white people. They fail to recognize that other people also have thoughts about God and have something significant to say about Jesus' presence in the world... My point is that one's social 
and historical context decides not only the questions we address to God, but also the mode or form of the answers given to the questions (Cone, 2008, p.14).

The overwhelming emphasis on a white theological education and white representation in the Faculty-staff body in America's theological schools demeans the significance of theological contextualization in the classroom and the necessity for more inclusive and multicultural religious training to serve non-Anglo churches and faith communities. To strengthen his claim, Cone's remarks on the racial identity and deficiency of white theological expression is worth noting further:

Theology is always identified with a particular community. It is either identified with those who inflict oppression or with those who are its victims. A theology of the latter is authentic Christian theology, and a theology of the former is a theology of the Antichrist...American white theology is a theology of the Antichrist insofar as it arises from an identification with the white community, thereby placing God's approval on white oppression of black existence. (2010:6)

The lack of ethnic and racial diversity in America's seminaries and divinity schools give the false impression that one size fits all. As Cone (2010: 6) has asserted, "In a racist society, God is never color-blind. To say God is color-blind is analogous to saying that God is blind to justice and injustice, to right and wrong, to good and evil."

Cone goes further to denounce the irrelevance of theological guilds and (American) theologians who are indifferent to the existential crises of the community named above, "It seems that much of this abstract theological disputation and speculation - the favorite pastime for many theological societies - serves as a substitute for relevant involvement in a world where men die for lack of political justice" (Cone, 2008:43). By contrast, the attentive theologian must see it as a Christian responsibility to address "what the gospel has to say to a man who is jobless and cannot get work to support his family because the society is unjust" (Cone, 2008:43).

Similarly, it is a moral duty for the Christian thinker to discuss openly the relevance of the Gospel to the woman who has been abused, beaten, raped, and oppressed in the hands of evil men. What does the Gospel have to say to the innumerable black and brown boys and girls who have no economic standing in society and who are orphans because of the repressive structural systems and societal-political arrangements against them that do not recognize their humanity and dignity simply because of the colour of their skin and that they do not belong to the dominant white culture? What is the meaning of Christian theology for the undocumented immigrants and illegal refugees from the Caribbean and Latin American countries currently incarcerated in American prison cells just because they are here to seek a bet- 
ter life in America? Does the Christian Gospel have any relevance to the thousands of refugee children American Border Policies have illegally snatched away from their parents' hands at the U.S. Mexican borders? What does Christian theology have to say to the oppressed communities in earnest search for economic mobility, political rights, and social equality in their own land? How should Christian theologians help the oppressed community cope with and overcome Police brutality and the burden of racial injustices, hunger, and poverty in the "Land of Freedom" and the "Land of the Braves?" Cone interrogates the problematic nature of American theology, and it is a legitimate and relevant concern that Christian theologians and clergy should contemplate in their contemporary times:

Unless there is a word from Christ to the helpless, then why should they respond to him? How do we relate the gospel of Christ to people whose daily existence is one of hunger or even worse, despair? Or do we simply refer to them to the next world? (2008:43-4).

To move forward in our analysis, in his seminal text, The Cross and the Lynching Tree, Cones attempts to recapitulate the American narrative of terror and viciousness toward the country's black citizens and the inadequacy of white theologians to address constructively with the wisdom of the Christian gospel and the terrific message of the cross the crisis of black death and black dehumanization motivated by white (aggressive) rage and (intense) hatred. Writing with deep personal anguish and discontent, he reflects profoundly on the historical trajectories of his life:

I found my voice in the social, political, religious, and cultural context of the civil rights and black power movements in the 1960s. The Newark and Detroit riots in July 1967 and the assassination of Martin Luther King Jr. in April 1968 were the events that shook me out of my theological complacency, forcing me to realize that bankruptcy of any theology in America that did not engage the religious meaning of the African American struggle for justice... Silence on both white supremacy and the black struggle against racial segregation made me angry with a fiery rage that had to find expression. How could any theologian explain the meaning of Christian identity in America and fail to engage white supremacy, its primary negation? (Cone, 2011: xvi-xvii).

For Cone, the three great historical heresies and antitheses to the Gospel in America are anti-black racism, the silence of white churches about social justice issues and the plot of the poor, and the silence of white theologians on black death and alienation in the American society. Cone suggests, however, it was "self-interest and power corrupted their understanding of the Christian gospel" (Cone, 2011:xvi-xvii) that motivated many white theologians and many whites who confessed the Christian 
faith to support the social evils of three-and-a-half-centuries of slavery and a century of racial segregation. It is within these historical trajectories and particularly the history of black suffering that Cone (2010: xii) could write reactionally, "If theology had nothing to say about black suffering and resistance, I could not be a theologian." To substantiate Cone's above thesis, we shall provide various forms and articulations of America's cultural and theological predicament.

\section{The Crisis of White Theological Discourse}

The prominent Swiss-born American church historian Philip Schaff (1819-1893), a proponent of white supremacy and pro-slavery theologian articulated an ambivalent view on race relations. He defended the institution of slavery through his publication. Schaff energetically contended that slavery would one day be recognized in the American society as "no doubt an immense blessing to the whole race of Ham" (Noll, 2009:51) he was also convinced that "The Negro question, lies far deeper than the slavery question" (p.51). Unquestionably, Schaff strongly believed that "The AngloSaxon and Anglo-American, of all modern races, possess the strongest national character and the one best fitted for universal domination" (Cone, 2011:p. 6).

Similarly, the eminent 19th century Reformed theologian and Professor of Theology at Princeton Theological Seminary Charles Hodge (1797-1878) was a slave owner and therefore did not view slaveholding as a sin or America as a slaveholding Christian nation as contrary to biblical ethic (Torbett, 2006:79). In the "Slavery" article, penned in 1836, he claimed nowhere in the New Testament that Christian slave masters are commanded to emancipate their slaves: "If we are right in insisting that slaveholding is one of the greatest of all sins; that it should be immediately and universally abandoned as a condition of church communion, or admission into heaven, how come is it that Christ and his apostles did not pursue the same course?" (Gutjahr, 2012:172).

White theology coupled with the question of race in the antebellum America indicates that the slaveholding America was morally bankrupt, and that the nation must undergo a radical evaluation of ideals and values. It also signals that, in principle, slaveholding contributed to the moral failure of Christian America and American Christianity, equally. The French philosopher Diderot, in his anti-slave trade article and argument against the institution of slavery, correspondingly, which he co-published with Alembert in the first modern encyclopedia (Encyclopedie, 1751-77), denounces, "If a trade of this sort can be justified by some principle of morals, there is no crime, however atrocious, that one could not legitimate" (Appiah, 2011:109).

When a particular theological expression articulates such a conviction, or a theological system promotes such a (human) practice, it invites us to assess the 
seriousness of its message and its relevance to human flourishing. Cone (2010:35), however, reminds us that "The black church in America was founded on the belief that God condemned slavery and that Christian freedom meant political emancipation." How can a society flourish when one group progresses, and the other group suffers oppression and exploitation and is deprived of its goods?

Incontestably, human suffering is too urgent in our contemporary times and the omnipresence of evil in our city and the modern world threatens every area of human existence for theologians to focus exclusively on theological jargons of Christian theology and to be disengaged with the realities of the moment. The fragility of human life, the uncertainty of the present, and the vacillation of future possibilities should be sufficient reasons for theology to be the most relevant guide to our existential troubles and challenges. It is critical for Christian religious thinkers to use their craft aptly to foster hope and healing. About this pivotal matter, cone could write convincingly, "With clever theological sophistication, white theologians defined the discipline of theology in the light of the problem of the unbelievers (i.e., the question of the relationship of faith and reason) and thus unrelated to the problem of slavery and racism" (Cone, 2010:35). White theologians do not question the system that produces the subjugation and abuse of the poor and people of colour, and the culture of despair that engenders hostility in society. Human domination is taken for granted in American theological inquiry, resulting in a theology that is incapable to respond adequately to the needs of the people and the demise of American civilization.

The issue at stake is that American white theologians have turned off the economic, political, or social concern at will in most human contexts, as if it were not part of their lifeblood (Assmann, 1976:9). The pressing matter is that human suffering should be interpreted as a profound theological problem, and theologians must provide hope to the abused, the exploited, and the damned; theologians must speak of God's liberating presence to the common people in society. Likewise, they must confront the moral matters of their culture and this age. Christian theology must provide an adequate answer to individuals trapped in the socio-economic difficulties and political uncertainties in society.

Finally, Cone makes a resounding case for moral and ethical reform within American Christianity and the practices of American churches. He declares, "If white Protestant churches failed to be a beacon of leadership in America's racial crisis, part of the responsibility for the failure was due to the way its leading religious spokespersons ignored race in their interpretation of the Christian faith" (Cone, 2011:57). To put is simply, weak churches may have devastating effects on the life of the people in society. Evangelical historian Mark Noll, who traces the causes associated with Christianity in the mid- nineteenth 19th century American 
culture, writes observably, "One momentous-by-product of religious expansion was the fact that the institutional life of the major Protestant churches worked an echoing effect on the body politic (Noll, 2009:27).

In his acclaimed text, Theology in America, historian E. Brooks Holifield highlights some of the major shortcomings associated with White American theology including the inability of white theologians to mobilize the American people toward better race relations (i.e. unity and reconciliation) and to transcend the cultural pitfalls and political differences between white and black Christians. These concerns are thus followed: (1) "the theological impasse meant that theology could no longer articulate the moral vision that held that culture together" (Holifield, 2008:503); (2) for others, theology is unable "to unite Americans or to help them transcend the pull of economic and political interests"(Ibid), and finally, (3) "The cultural language that supposedly united Americans proved itself able to contribute even more forcefully to their division" (Ibid). What should then be the task of theology in the life of the church and in culture in 21st century?

\section{The Task of Christian Theology}

One of the major theological questions in Western theological tradition has been the concerns for proper theological method and structure. Theologians have not arrived at a consensus on the underlying role of Christian theology. Equally, various propositions about the task of Christian theology in the church and society that have been suggested often conflict each another. For example, Reinhold Niebuhr (2013:9) construes the chief role of theology as "an effort to construct a rational and systematic view of life out of the various and sometimes contradictory myths which are associated with a single religious tradition." In the introductory page of his well-praised Systematic Theology (Volume One), Paul Tillich (1973:3) establishes a strong rapport between theology and the life of the church; he interprets theology as a function of the Christian church, that is, theological conversations must emerge from the practices and experiences of the people of God, and that the basic task of theology is to respond satisfactorily to the needs of the church. Hence, theology is simply "the statement of the truth of the Christian message and the interpretation of this truth for every new generation" (Tillich, 1973:3).

The content, shape, and method of theological discourse is created within the ideological worldview of the given culture, as well as in the socio-political, and the historico-cultural trajectories of the associated generation. Karl Barth in Cburch Dogmatics articulates a similar perspective that Christian theology is an impossible enterprise without the active participation and experience of humanity, and that divine revelation enlists men and women into service. The idea of theology as service in Barth is central in Cone's theological development; the notion denotes that God 
has chosen the church in society to be a community that fosters healing, care, comfort, and hospitality, and that "the work of theology is thus wholly related to the task of the Church which is that of every Christian" (Barth, 1994, pp.:81-2). Therefore, divine revelation has called followers of Christ to work collaboratively to restore the broken humanity and to integrate men and women into the beloved community of Christ Jesus toward a better humanity, as God himself continues to effect renovation in society through the cooperation and submission of his ambassadors (the church as people of God) in the world.

Moreover, in Towards Christian Political Ethics, Liberation theologian Jose Miguez Bonino (2007:39) advises that the engaged theologian should carefully examine the dialectic of praxis and theory in theological analysis, and the end of such endeavor is not to produce a perfect harmonization between these two poles; "on the contrary, instead of a balanced harmony we must think in terms of two poles that challenge each other, making change and movement possible." For Bonino, human action should challenge the theory that has informed it, and human thought should drive action to new explorations; to put it another way, the reality individuals create should transform human (their) action, and action is oriented toward and by that reality (Bonito, 2007:39).

From this vantage point, the conscious theologian should be mindful that every human act has both a social and political content, and that "a theology of the historico-political development of man is only possible in so far as it relates to an ethic of change, and in so far it accepts political action as a means of transforming society" (Assmann, 1976:33). In the words of Clodovis Boff (2009:xxi), Black and Liberation theologies (i.e. Womanist, Feminist, Third World, Postcolonial, indigenous) call for "a positive, contextual, and concrete knowledge of society...the theology of liberation pleads for a reading of Scripture in continual mindfulness of and orientation to concrete challenges and problems... it appears as a demand of the praxis of faith, to the extent that this faith seeks to be incarnate".

In addition, James Cone and the religious thinkers who labor from liberationist and constructive theological angles find some serious shortcomings within the contours and workings of the Western theological canon; in the words of Cone:

There is no "abstract" revelation, independent of human experience, to which theologians can appeal for evidence of what they say about the gospel. God meets us in the human situation, not as an idea or concept that is self-evidently true. God encounters us in the human condition as the liberator of the poor and the weak, empowering them to fight for freedom because they were made for it. Revelation as the word of God, witnessed in Scripture and defined by the creed and dogmas of Western Christianity, is too limiting to serve as an adequate way of doing theology today (2010: xiv). 
Cone (2008:39) has advanced that the goal of Christian theology, whether confessional or public theology, is "the liberation of man" and woman. By providing a succinct definition of the discipline, he asserts clearly that "Theology is not only rational discourse about ultimate reality; it is also a prophetic word about the righteousness of God that must be spoken in clear, strong, and uncompromising language" (Cone, 2010:xii). Cone questions the validity and relevance of Western theological tradition that often seeks to supply "the rational justification of religious belief in a scientific and technological world that has no use for God" (Cone, 2010:xiv) while ignoring the problems of this age and the urgent care for the poor in society. With personal conviction, he declares unapologetically, "When I thought about the long history of black suffering and the long silence of white theologians in its regard, I could not always control my pen or my tongue. I did not feel that I should in any way be accountable to white theologians or their cultural etiquette" Ibid:xv). Understandably, Cone's theology is a political theology that is concerned primarily with the personhood and dignity of black people. Critics often find shortcomings in Cone's Negritudinist theology and the absence of theo-political analysis on the economic disfranchisement of the poor and blacks.

Cone's political theology has two dimensions: the human aspect and the political consciousness coupled with social action. He construes the role of liberation theology as a revolutionary force in society that should not accept the "established order;" it must disturb it, alter its content, and deracinate its unjust structures. To put it simply, "such a political theology has to desacralize not only nature, but all the institutions of the status quo. It also has to put the new institutions brought about change in a human perspective. It must ever accept the ethics of the 'establishment"' (Assmann, 1976:33). The great impetus of Cone's theological corpus is human flourishing and wholistic shalom in society, and the welfare and freedom of the poor and the sweeping renovation of societal powers and forces in which they live.

\section{Theology and the Quest for Human Flourishing}

Theology must always be an on-going exercise as time changes and society evolves for good or bad. The theological task as that which it is emerged from "the covenant community with the sole purpose of making the gospel meaningful to the times in which men live" (Cone, 2008: 31). The essence of the Gospel message is unchanged, and it remains the same regardless of the crisis of the time; nonetheless, as Cone proposes, "every generation is confronted with new problems, and the gospel must be brought to bear on them. Thus, the task of theology is to show what the changeless gospel means in each new situation" (Cone, 2008:31). However, since theology is always contextual, and the message of the Gospel is transcultural and transracial, Christian theology, shaped by the redemptive news of Christ, must 
respond directly to the black condition in American and the living and economic situations of the vulnerable in their respective country-especially individuals in the developing world living under the constant threat and ruse of American-European imperialism, and the neo-colonial and economic global capitalism. Theologians should not ignore the real nature of society-the rapport between infrastructure and superstructure, the socioeconomic determinations, cultural and political ideologies, the nature of the state - and the ways that social dynamics have shaped theological language and exposition, as well as theological praxis (Bonino, 2007:37).

Toward the quest for human flourishing, Christian theologians must participate enthusiastically in public advocacy and render satisfactory civic service toward the common good. As the Gospel is about human liberation, salvation, and optimism, when the oppressed of the world "begin to hear Jesus' message as contemporaneous with their life situation, they will quickly recognize that the "political hermeneutics of the gospel" (Cone, 2008:36). Christianity becomes for them "a religion of protest against the suffering and affliction of man" (Ibid), which Jesus came to eradicate. This Jesus now dwells in the community of the world's poor, the afflicted, and the outcast who lodge in the ghetto of human despair and labyrinth of death; correspondingly, Jesus the Liberator lives among the postcolonial exploited individuals and families which American military forces and European interventionist powers have pushed in the margins of society. Cone teaches us that the relevance of Jesus' liberating message is not only good for the black and brown people in America; the person and work of Jesus is a life-changing experience to the orphan in the streets of Cape Town, South Africa; the widow in the shanty towns in Haiti and Jamaica; the mine worker in Ghana and Kenya; the sugar cane workers in the sugar industry in Dominican Republic and Cuba; the undocumented African immigrants in the ghetto of Paris and Tel Aviv; and the single mother in the war zone in Afghanistan and Pakistan.

If we can believe the New Testament witness which proclaims Jesus as resurrected and thus active even now, then he must be alive in those very men who are struggling in the midst of misery and humiliation. If the gospel is a gospel of liberation for the oppressed, then Jesus is where the oppressed are and continues his work of liberation there. Jesus is not safely confined in the first century. He is our contemporary, proclaiming release to the captives and rebelling against all who silently accept the structures of injustice. If he is not in the ghetto, if he is not where men are living at the brink of existence, but is, rather, in the easy life of the suburbs, then the gospel is a life (2008:38).

On a personal level, Cone, reflecting on the tragic collective experience of Black Christians in the segregated Bearden, Arkansas in the 1950s and 1960s who came 
face to face with white terror and white supremacy, writes optimistically and courageously about the meaning of Jesus in their everyday life; Jesus was a:

trusted friend who understood their trials and tribulations in this unfriendly world... Jesus was always there, as the anchor of life, giving it meaning and purpose and bestowing hope and faith in the ultimate justice of things. Jesus was that reality who empowered black people to know that they were not the worthless human beings that white people said they were (Cone, 2007:p.3).

Consequently, contemporary theological reasoning must promote a Christology that empowers the weak toward self-liberation and collective agency, as well as a doctrine of Christ that boasts about the enduring presence of Jesus the Deliverer among the economically-disfranchised poor, and the disadvantaged races and ethnic groups in the world. In Cone's Christology, the oppressed is always the protagonist and actor by the virtue of Jesus' intentional closeness and solidarity with them. The Christian theologian should commit to the struggle and deliverance of the underrepresented individuals and families in society; he or she must attempt to create a new theological language that prioritizes the plot of the underserved population and the historical fight of the poor for justice, equity, and rights.

In addition, In A Black Theology of Liberation, Cone introduces the threefold tasks of Christian theology:

1. The task of theology is to explicate the meaning of God's liberating activity so that those who labor under enslaving powers will see that the forces of liberation are the very activity of the being of God. Rather, it is a study of God's liberating activity in the world, God's activity on behalf of the oppressed (Cone, 2008:3).

2. The task of Christian theology is to analyze the meaning of hope in God in such a way that the oppressed community of a given society will risk all for earthly freedom, a freedom made possible in the resurrection of Jesus. The language of theology challenges societal structures because it is inseparable from the suffering community (Cone, 2008:4).

3. The task of (black) theology is to analyze the nature of the gospel of Jesus Christ in the light of (the experience of) the oppressed (blacks) so they will see the gospel as inseparable from their humiliated condition, and as bestowing on them the necessary power to break the chains of oppression (Cone, 2008:5).

In God of the Oppressed, Cone articulates three complementary tasks and roles of the Christian theologian as an exegete, a teacher, and a preacher. Each function relates to his work in the church and responsibility in society: 
1. The task of the theologian, as a member of the people of God, is to clarify what the Church believes and does in relation to its participation in God's liberating work in the world. In doing this work, the theologian acts in the roles of exegete, prophet, teacher, preacher, and philosopher (Cone, 2008:8).

2. The task of the theologian is to probe the depths of Scripture exegetically for the purpose of relating that message to human existence...this task involves, as Abraham Heschel said, the "exegesis of existence from a divine perspective", disclosing that God is not indifferent to suffering and not patient with cruelty and falsehood (Cone, 2008:8).

3. The task of theology is to show the significance of the oppressed struggle against inhuman powers, relating the people's struggle to God's intention to set them free. Theologians must make the gospel clear in a particular social context so that God's people will know that their struggle for freedom is God's struggle too (Cone, 2008:90-1).

On the other hand, he interprets the discipline of theology as a cross-cultural dialogue and intellectual activity in which the theologian engages energetically the lived-worlds and lived-experiences of the people living in the periphery of postcolonial nation-states; as he notes below:

I am convinced that no-one should claim to be doing Christian theology today without making the liberation of the Third World from the exploitation of the First World and the Second World a central aspect of its purpose. There is an interconnectedness of all humanity that makes the freedom of one people dependent upon the liberation of all (Cone, 2010:xvii).

Liberation theology as a subset of Biblical theology allows the Christian thinker or theologian to always be in connection with the subject and object of his or her inquiry. Biblical theology as the theology that liberates and connects with the poor calls for genuine relationship with the community of faith. One cannot work toward the integral liberation of the poor and the dispirited while separating oneself from their real presence or social reality. Liberation theology is a theology of proximity, interconnectedness, and relationship. It is plausible for Cone (2010: xix) to assume that "Theology is always done for particular times and places and addressed to a specific audience. This is true whether theologians acknowledge it or not. Although God is the intended subject of theology, God does not do theology, human beings do theology." Elsewhere, he clarifies that "if theology is to be relevant to the human condition which created it, it must relate itself to the questions which arise out of the community responsible for its reason for being" (Cone, 2010:36). As human liberation is the telos of Christian theology, Cone could define the discipline of theology as: 
a rational study of the being of God in the world in light of the existential situation of an oppressed community, relating the forces of liberation to the essence of the gospel, which is Jesus Christ. This means that its sole reason for existence is to put into ordered speech the meaning of God's activity in the world, so that the community of the oppressed will recognize that its inner thrust for liberation is not only consistent with the gospel but it is the gospel of Jesus Christ. There can be no Christian theology that is not identified unreservedly with those who are humiliated and abused. In fact, theology ceases to be a theology of the gospel when it fails to arise out of the community of the oppressed (Cone, 2010:1).

\section{Theology and Social Activism}

In the most fundamental Barthian dialectics, Cone's theology begins with God's revelation to the needs of humanity and maintains that theological inquiry should not start from human needs to God. Therefore, the ethos of the incarnation is that God has intervened in the human situation as to deliver humanity from the predicament of sin and human oppression (Cone, 2008:90). The God of the Bible, he contends, "stands against the culture of the oppressors" (Cone, 2008:89) and social injustice and inequality that often delay human flourishing and the common good. To borrow a central principle from the Latin American Theology of Liberation, "Protestant theology needs to recover not the one history, but the one just God as the radical counterforce of all unjust history" (Assmann, 1976:7), including the history of women oppression and abuse in the church and in society. Further, Cone also suggests that theology should address contemporary problems of sexism in the church, classism in society, the downsides of capitalism and globalization, and the exploitation of the developing nations by the developed nations. Correspondingly, the task of Christian theology today is to denounce the quandary of poverty, world hunger, colonialism, human rights, and the monopoly capitalism of the U.S. and the (Western) European nations in Latin America, Africa, the Caribbean, and Asia (Cone, 2010: xvi-xx).

Concerning the question of sexism in Christian churches, Cone believes that "sexism dehumanizes and kills, and it must be fought on every front. . .Anyone who claims to be fighting against the problem of oppression and does not analyze the exploitive role of capitalism is either naive or an agent of the enemies of freedom" (Cone, 2010: xvi-xvii). Therefore, the critical theologian must not analyze the race question apart from the effects of capitalism on race, class, and gender; racism, classism, sexism, and capitalism are the worst antagonists of human deliverance and self-determination. Sexism postpones women's freedom and agency and undermines Christian women's use of their gifts in the church to empower the community of faith.

Particularly, as much as racism is America's original sin that has affected millions of American poor and specifically the black and brown (oppressed) population, Cone 
reckons that American theologians should examine the human condition and not simply the issue of American racism. It is from this viewpoint he could make this declaration: "We must not allow racial solidarity to distort the truth. Without class analysis, a global understanding of oppression will be distorted and its domestic manifestations seriously misrepresented" (Cone, 2010: xviii). While racial solidary can be effective at certain moments of struggle, human unity is the transcendent value that outdoes the problem of race, sexism, and classism in the church and society.

Cone's stated claim above is justified that it is necessary for the Christian theologian to be both a nationally and internationally-minded, and culturally and transculturally-concerned thinker as the issues he or she analyzes engulf the human condition in the world.

[Theologians] must be concerned with the quality of human life not only in the ghettos of American cities but also in Africa, Asia and Latin America. Since humanity is one, one cannot be isolated into racial and national groups, there will be no freedom for anyone until there is freedom for all. This means we must enlarge our envision by connecting it with that of other oppressed so that together all the victims of the world might take charge of their history for the creation of a new humanity... .Liberation knows no color bar; the very nature of the gospel is universalism, i.e., a liberation that embraces the whole of humanity (Cone, 2004:271-4).

\section{Conclusion}

The clarion call for contemporary Christian theology is to be a theology for the people and from the people. Theology from below should never be the articulation of theoretical ideas that can't reach the ear of the poor and the uneducated and are inaccessible to their understanding. The theology of tomorrow must remain true to its never-ending search for comprehensive justice and steadfast commitment to the good of the poor, the orphan, the widow, the abused, the victim, and the exploited. The global perspective in theology would enable the engaged Christian thinker to give careful attention to the struggles of the troubled population in his or her own country and be proactive about the cries for justice from the lips of mistreated racial and ethnic groups in other parts of the world. Within this line of reasoning, Cone offers some words of wisdom and exhortation:

The Christian theologian, therefore, is one whose hermeneutical consciousness for an interpretation of the gospel defined by the oppressed people's struggle of freedom, seeking to adhere to the delicate balance of social existence and divine revelation. In this situation, the theologian must accept the burden and the risk laid upon him or her by both social existence and divine revelation, realizing that they must be approached dialectically, and thus their exact relationship cannot be solved once and for all time (Cone, 2008:89). 


\section{Bibliography}

Assmann, H. (1976). Theology for a Nomad Church. New York: Orbis Books.

Ahlstrom, S.E. (2004). A Religious History of the American People. New Haven: Yale University Press.

Appiah, K.A. (2011). The Honor Code: How Moral Revolution Happens. New York: Norton. Barth, K. (1994). Church Dogmatic. Louisville: Westminster John Knox Press.

Bigo, P. (1977). The Church and Third World Revolution. New York: Orbis Books.

Boff, C. (2009). Theology and Praxis: Epistemological Foundations. Eugene: Wipf \& Stock.

Bonino, J.M. (2007). Toward a Christian Political Ethics. Minneapolis: Fortress.

Cone, J.H. (2004). "Black Theology and the Black Church: Where Do We Go from Here?” In: James H Cone and Gayraud S Wilmore, eds., Black theology: A Documentary History. 1, 1966-1979. New York: Orbis Books, pp. 266-275.

Cones, J.H. (2007). "Looking Back, Going Forward: Black Theology as Public Theology." In: Dwight N. Hopkins, ed., Black Faith and Public Talk: Critical Essays on James H. Cone's Black Theology and Black Power. Waco: Baylor University Press, pp. 246-259.

Cone, J.H. (2008). Black Theology and Black Power. New York: Orbis Books.

Cones, J.H. (2008). God of the Oppressed. New York: Orbis Books.

Cones, J. H. (2010). A Black Theology of Liberation. Fortieth Anniversary Edition. New York: Orbis Books.

Cone, J. H. (2011). The Cross and the Lynching Tree. New York: Orbis Books.

Gutjahr, P.C. (2012). Charles Hodge: Guardian of American Orthodoxy. New York: Oxford University Press.

Holifield, E.B. (2008). Theology in America Christian Thought from the Age of the Puritans to the Civil War. New Haven: Yale University Press.

Johnson, L.T. (1986). Sharing Possessions: Mandate and Symbol of Faith. London: SCM Press.

Kendi, I.X. (2016). Stamped from the Beginning: The Definitive History of Racist Ideas in America. New York: Nation Books.

Mather, C. (1706). The Negro Christianized. UNL Digital Commons - University of Nebraska-Lincoln. Available at: https://digitalcommons.unl.edu/cgi/viewcontent. cgi? article $=1028 \&$ context=etas. [Accessed July 28, 2018] .

McKivijan, J.R. and Snay, M. (1998). Religion and the Antebellum Debate Over Slavery. Athens: University of Georgia Press.

Mosala, I.J. (1989). Biblical Hermeneutics and Black Theology in South Africa. Grand Rapids: William B. Eerdmans Publishing Company.

Niebuhr, R. (2013). Moral Man and Immoral Society: A Study in Ethics and Politics. Louisville: Westminster John Knox Press.

Niebuhr, R. (2013). An Interpretation of Christian Ethics. Louisville: Westminster JohnKnox Press.

Noll, M.A. (2009). The Civil War as a Theological Crisis. Chapel Hill: University of North Carolina Press.

Paris, P.J. (1985). The Social Teaching of the Black Churches. Philadelphia: Fortress Press. 
Staffin, John. (1997). "A Brief and Candid Answer." In: Myriam Jehlen and Michael Warner, (eds.), The English Literatures of America: 1500-1800. Hoboken: Taylor and Francis, pp.821-824.

Tillich, P. (1973). Systematic Theology. Volume One. Chicago: University of Chicago.

Torbett, D. (2006). Theology and Slavery: Charles Hodge and Horace Bushnell. Macon: Mercer University Press.

The Universal Declarations of Human Rights. (1948). United Nations.Available at: http:// www.un.org/en/udhrbook/pdf/udhr_booklet_en_web.pdf. [Accessed July 28, 2018].

Vellem, V. (2012). Interlocution and Black Theology of Liberation in the 21st century: A Reflection. Studia Historiae Ecclesiaticae, 38, 345-360.

Vellem, V. (2015). Black Theology of liberation: A Theology of Life in the Context of Empire. Verbum et Ecclesia, 36(3), Art. 14760, pp.1-6. 